\title{
Effect of Zinc Sulphate on Vegetative Growth, Yield and Leaf Nutrient Status of Guava (Psidium guajava L.)
}

\author{
Brijpal Bisen $^{1^{*}}$, J. P. Tiwari ${ }^{2}$, K. K. Mishra ${ }^{2}$ and Shant Lal ${ }^{2}$ \\ ${ }^{1}$ Department of Horticulture, Jawaharlal Nehru Krishi Vishwa Vidyalaya, \\ Jabalpur (MP), India \\ ${ }^{2}$ G. B. Pant University of Agriculture and Technology, \\ Pantnagar - 263145 (Uttaranchal), India \\ *Corresponding author
}

A B S T R A C T

\begin{tabular}{|l|}
\hline Ke y w o r d s \\
Guava, zinc \\
sulphate, Pant \\
Prabhat and ZnSO4 \\
\hline Article Info \\
\hline $\begin{array}{l}\text { Accepted: } \\
\text { 11 June } 2020 \\
\text { Available Online: } \\
\text { 10 July 2020 }\end{array}$ \\
\hline
\end{tabular}

\section{Introduction}

Guava (Psidium guajava L.) is one of the well known edible fruit of the tropical and subtropical climates and is also referred as "apple of tropics". Due to its hardy nature, drought tolerance, high yield potential and diverse uses of fruits, the crop has gained ideal position for scarcity zones also where other fruits cannot be grown successfully. The fruit (berry) is an excellent source of vitamin C and pectin. Additionally, it is also abundant in dietary fibres, vitamin A (about 250 IU/100 $\mathrm{g}$ ), calcium, phosphorus and iron. It is normally consumed fresh as a dessert fruit, excellent salad and pudding are prepared from the shell of ripe fruit (Jagtiani et al., 1988). Guava makes the best jelly, besides this, jam, sharbat, ice cream, cheese, canned fruit, RTS, nectar, squash and guava powder are also made. Two types of wines viz., guava juice and guava pulp wines are also prepared from guava fruits (Bardiya et al., 1974). The roots, bark, leaves and green fruits are used as medicine in the tropical world to halt gastroentities, diarrhea and dysentery (Rathore, 1976). 
Under North Indian conditions, guava bears twice in a year, known as rainy and winter season crop. Winter season crop is preferred for commercial use. The trees grown under field conditions are subjected to nutrient deficiencies which affect the growth, tissue composition, fruit production and quality. Among the different essential mineral nutrients, zinc $(\mathrm{Zn})$ is an important micronutrient involved in enzymatic systems essential for protein synthesis, seed production and rate of maturity in plants (Swietlik, 1999 and 2002). It is required for synthesis of tryptophan, which is a precursor of indole acetic acid. It also plays an important role in starch metabolism in plants (Alloway, 2008). It is well known that $\mathrm{Zn}$ acts as a co-factor of many enzymes and affects many biological processes such as photosynthesis, nucleic acids metabolism, and biosynthesis of proteins and carbohydrates (Marschner, 1995).

The foliar feeding of fruit trees has gained much importance in recent years as fertilizers application through soil are needed in greater amount because some portion leaches down and some does not become available to the plant due to complex chemical reactions. Tarai soil is zinc deficient and symptoms of its deficiency have been observed in many crops. Although zinc deficiency has not been noticed in guava orchards in tarai area, there might be hidden hunger of zinc affecting the growth, yield and quality of guava. Therefore, the present investigation was undertaken to evaluate the effect of number of sprays and concentration of zinc sulphate on yield and leaf nutrient status in winter season crop of guava cv. Pant Prabhat.

\section{Materials and Methods}

The experiment was conducted at the 'Horticultural Research Centre, Pattharchatta of Govind Ballabh Pant University of
Agriculture and Technology, Pantnagar, Distt. Udham Singh Nagar (Uttarakhand) on two year old guava trees cv. Pant Prabhat and trees were maintained under uniform cultural schedule.

The experimental was laid out in two factor randomized block design. All the treatments were replicated thrice and two trees served as a unit of treatment in each replication. The plants were sprayed with different concentrations of zinc sulphate $(0.2,0.4$ and $0.6 \%$ ) and water spray (control). The spraying was done with the help of a foot sprayer, using 0.1 per cent 'Teepol' as surfactant. Treatments were given in June and September, and leaf sampling was done in the month of October.

The height of the tree was measured from the ground level to the highest crown level with the help of a measuring pole. The canopy was measured in both the direction i.e. East-West and North-South and calculated by the formula $(\mathrm{N}-\mathrm{S})+(\mathrm{E}-\mathrm{W}) / 2$. The trunk diameter was measured with the help of vernier calipers at the marked point i.e. $10 \mathrm{~cm}$ above ground level and was presented in centimeters and calculated by the formula $(\mathrm{N}-\mathrm{S})+(\mathrm{E}-$ $\mathrm{W}) / 2$. The tree volume was calculated as per formula:

\section{Tree volume $=4 / 3 \pi a^{2} b$}

[Where, $\pi=3.14, a=1 / 2$ of the spread (m) and $b=1 / 2$ of the tree height $(\mathrm{m})]$

The shoot length was measured in $\mathrm{cm}$ by using a meter scale at 4 months interval for each treatment. In studying the flower drop and fruit set, four branches per tree in all the found directions were tagged on each tree and number of flowers and fruits were counted and mean weight $(\mathrm{g})$ of fruits was calculated by taking weight of five fruits, divided with number of fruits (i.e. 5). Yield tree was 
calculated by manual counting of total fruits per tree and multiplying with mean fruit weight $(\mathrm{g})$. Whereas fruit yield per ha was calculated by multiplying the mean yield per tree with number of trees per ha in each treatment.

Five - month -old leaves from the previously tagged non fruiting shoots were taken for the study of mineral composition of leaves and 20 pairs of leaves were sampled from $4^{\text {th }}$ and $5^{\text {th }}$ positions from the base of shoots spread over all the direction of the plants. The collected leaves samples were washed in tap water and then rinsed in $0.1 \mathrm{~N} \mathrm{HCl}$ followed by three successive rinsing with single distilled water. Thereafter, the leaves were washed with double distilled water. Washed samples were placed in butter paper bags and dried in the oven at $65{ }^{0} \mathrm{C}$ for 48 hours to get constant dry weight. The leaf samples were grounded with a Willey's Mill to powder form for further analysis purpose. Nitrogen, phosphorus and potassium contents were estimated by the micro-kjeldhal method (AOAC, 1970), Vanado molybdophosphoric yellow collar method (Jackson, 1973) and flame photometric methods, respectively. Calcium and magnesium were estimated by Versanate (EDTA) method (Chang and Bray, 1951). Zinc was determined directly feeding di-acid digest in atomic absorption spectrophotometer.

\section{Results and Discussion}

\section{Effect of zinc sulphate on vegetative growth}

The data presented in Table 1 clearly indicated that the number of foliar sprays and various concentrations of zinc sulphate did not affect the tree height and it was in conformity with the results of Switlik and Laduke (1991). The interaction between foliar sprays and concentrations of zinc sulphate was found to be significant for tree height. The maximum increase in plant height was found with double spray x $0.6 \%$ zinc sulphate combination. Similar results were also found in case of tree canopy (Bahadur et al., 1998 and Banik and Singh, 1997), trunk diameter and tree volume. However, the increase in shoot length was higher in trees with higher concentrations of zinc sulphate.

The increase in shoot length may be ascribed to $\mathrm{Zn}$ in its capacity as a constituent of carbonic anhydrase, which is an important enzyme involved in the photosynthesis. It has been demonstrated that without the activity of this enzyme a 50-70\% reduction in net photosynthesis may occur depending on the plant species and the severity of deficiency, consequently reducing the food reserves and adversely affecting tree growth (Alloway, 2008). Similarly, the above result is in conformity with the results of Jawanda (1966), Manchanda (1967) and Dutt and Bhambata (1967) in citrus, Dawood et al., 2001 in Sweet Orange and Razzaq et al., 2013 in Kinnow Mandrin.

\section{Effect of zinc sulphate on flower and fruit drop percentage}

Data presented in Table 2 revealed that the maximum flower drop and fruit drop was observed with control, while minimum was found with higher concentrations of zinc sulphate. Trees sprayed with $0.6 \%$ zinc sulphate exhibited the highest reduction in the pre-harvest fruit drop percentage compared to control tree. The effect of zinc sulphate on reduction of flower drop might be due to increased concentration of auxin in shoots as zinc plays a major role in tryptophan synthesis which is a precursor of auxin biosynthesis which consequently improves the endogenous level of auxins at abscission zone to avoid flower and fruit drop. 
Table.1 Effect of foliar sprays and various concentrations of zinc sulphate on vegetative growth

\begin{tabular}{|c|c|c|c|c|c|}
\hline Treatment & $\begin{array}{c}\text { Increase in tree } \\
\text { height }(\%)\end{array}$ & $\begin{array}{c}\text { Increase in tree } \\
\text { canopy }\end{array}$ & $\begin{array}{c}\text { Increase in trunk } \\
\text { diameter }(\%)\end{array}$ & $\begin{array}{c}\text { Increase in tree } \\
\text { volume }(\%)\end{array}$ & $\begin{array}{c}\text { Increase in shoot } \\
\text { length }(\%)\end{array}$ \\
\hline \multicolumn{6}{|l|}{ Number of foliar sprays } \\
\hline Single (June) & $\begin{array}{r}22.34 \\
(28.90)\end{array}$ & $\begin{array}{c}23.27 \\
(28.70)\end{array}$ & $\begin{array}{c}25.55 \\
(30.28)\end{array}$ & $\begin{array}{c}78.85 \\
(62.85)\end{array}$ & $\begin{array}{r}53.61 \\
(47.09)\end{array}$ \\
\hline Double (June + September) & $\begin{array}{c}24.21 \\
(29.39)\end{array}$ & $\begin{array}{c}25.03 \\
(29.97)\end{array}$ & $\begin{array}{c}26.43 \\
(30.90)\end{array}$ & $\begin{array}{r}78.08 \\
(62.89)\end{array}$ & $\begin{array}{r}50.72 \\
(45.41)\end{array}$ \\
\hline S.Em \pm & $(0.67)$ & $(0.56)$ & $(0.78)$ & $(1.66)$ & $(\mathbf{0 . 8 3 )}$ \\
\hline C.D. at $5 \%$ & NS & NS & NS & NS & NS \\
\hline \multicolumn{6}{|c|}{ Zinc sulphate concentration (\%) } \\
\hline 0.2 & $\begin{array}{r}23.46 \\
(28.82)\end{array}$ & $\begin{array}{l}22.49 \\
(28.10)\end{array}$ & $\begin{array}{r}24.82 \\
(29.78)\end{array}$ & $\begin{array}{r}78.05 \\
(62.16)\end{array}$ & $\begin{array}{r}54.95 \\
(47.88)\end{array}$ \\
\hline 0.4 & $\begin{array}{c}20.61 \\
(26.90)\end{array}$ & $\begin{array}{c}26.40 \\
(30.64)\end{array}$ & $\begin{array}{c}25.77 \\
(30.44)\end{array}$ & $\begin{array}{c}78.11 \\
(63.48)\end{array}$ & $\begin{array}{c}45.63 \\
(42.48)\end{array}$ \\
\hline 0.6 & $\begin{array}{c}24.41 \\
(29.51)\end{array}$ & $\begin{array}{c}23.02 \\
(30.64)\end{array}$ & $\begin{array}{c}27.79 \\
(31.79)\end{array}$ & $\begin{array}{c}79.52 \\
(63.46)\end{array}$ & $\begin{array}{c}55.22 \\
(48.00)\end{array}$ \\
\hline Control & $\begin{array}{c}24.62 \\
(29.74)\end{array}$ & $\begin{array}{c}25.05 \\
(29.98)\end{array}$ & $\begin{array}{c}25.57 \\
(30.34)\end{array}$ & $\begin{array}{c}78.20 \\
(62.38)\end{array}$ & $\begin{array}{c}52.86 \\
(46.64)\end{array}$ \\
\hline S.Em \pm & $(0.95)$ & $(0.79)$ & (1.109) & $(2.35)$ & (1.17) \\
\hline C.D. at $5 \%$ & NS & $\mathbf{N S}$ & NS & NS & (3.56) \\
\hline
\end{tabular}

Figures in parenthesis indicate arcsine values 
Table.2 Effect of foliar sprays and various concentrations of zinc sulphate on yield parameters

\begin{tabular}{|c|c|c|c|c|c|}
\hline Treatment & $\begin{array}{l}\text { Flower drop } \\
(\%)\end{array}$ & Fruit drop (\%) & Fruits per tree & $\begin{array}{c}\text { Weight of fruits } \\
\text { (kg/tree) }\end{array}$ & Fruit yield (q/ha) \\
\hline \multicolumn{6}{|l|}{ Number of foliar sprays } \\
\hline Single (June) & $\begin{array}{r}36.22 \\
(36.98)\end{array}$ & $\begin{array}{c}13.58 \\
(21.61)\end{array}$ & 16.58 & 1.69 & 2.64 \\
\hline Double (June + September) & $\begin{array}{r}32.72 \\
(34.84)\end{array}$ & $\begin{array}{c}12.42 \\
(20.58)\end{array}$ & 23.15 & 2.45 & 3.82 \\
\hline S.Em \pm & $(0.69)$ & $(0.23)$ & 0.73 & 0.36 & 0.13 \\
\hline C.D. at $5 \%$ & 2.08 & 0.69 & 2.21 & 0.26 & 0.40 \\
\hline \multicolumn{6}{|c|}{ Zinc sulphate concentration (\%) } \\
\hline 0.2 & $\begin{array}{r}35.82 \\
(36.76)\end{array}$ & $\begin{array}{c}13.01 \\
(12.14)\end{array}$ & 20.67 & 2.15 & 3.36 \\
\hline 0.4 & $\begin{array}{c}32.75 \\
(34.89)\end{array}$ & $\begin{array}{c}12.59 \\
(20.76)\end{array}$ & 22.33 & 2.37 & 3.69 \\
\hline 0.6 & $\begin{array}{c}30.87 \\
(33.70)\end{array}$ & $\begin{array}{c}11.61 \\
(20.76)\end{array}$ & 24.08 & 2.58 & 4.03 \\
\hline Control & $\begin{array}{c}38.44 \\
(38.30)\end{array}$ & $\begin{array}{c}14.78 \\
(22.59)\end{array}$ & 12.37 & 1.18 & 1.84 \\
\hline S.Em \pm & $(0.97)$ & $(0.32)$ & 1.03 & 0.121 & 0.19 \\
\hline C.D. at $5 \%$ & 2.94) & 0.97 & 3.13 & 0.367 & 0.57 \\
\hline
\end{tabular}

Figures in parenthesis indicate arcsine values 
Table.3 Effect of foliar sprays and various concentrations of zinc sulphate on leaf N,P, K and Zn content on dry weight basis

\begin{tabular}{|c|c|c|c|c|c|}
\hline Treatment & $\mathbf{N}(\%)$ & $P(\%)$ & $\mathbf{K}(\%)$ & $\mathrm{Ca}+\mathrm{Mg}(\mathrm{Me} / \mathrm{l})$ & Zinc (ppm) \\
\hline \multicolumn{6}{|l|}{ Number of foliar sprays } \\
\hline Single (June) & $\begin{array}{l}1.008 \\
(5.75)\end{array}$ & $\begin{array}{l}0.227 \\
(2.77)\end{array}$ & $\begin{array}{l}0.536 \\
(4.18)\end{array}$ & 15.35 & 58.10 \\
\hline Double (June + September) & $\begin{array}{l}1.006 \\
(5.75)\end{array}$ & $\begin{array}{l}0.226 \\
(2.71)\end{array}$ & $\begin{array}{l}0.562 \\
(4.27)\end{array}$ & 13.06 & 120.39 \\
\hline S.Em \pm & 0.063 & 0.31 & 0.084 & 0.54 & 2.35 \\
\hline C.D. at $5 \%$ & NS & NS & NS & 1.65 & 7.12 \\
\hline \multicolumn{6}{|c|}{ Zinc sulphate concentration (\%) } \\
\hline 0.2 & $\begin{array}{l}0.988 \\
(5.70)\end{array}$ & $\begin{array}{l}0.254 \\
(2.89)\end{array}$ & $\begin{array}{l}0.607 \\
(4.38)\end{array}$ & 13.70 & 80.62 \\
\hline 0.4 & $\begin{array}{l}1.011 \\
(5.77)\end{array}$ & $\begin{array}{l}0.238 \\
(2.79)\end{array}$ & $\begin{array}{l}0.709 \\
(4.65)\end{array}$ & 13.08 & 95.20 \\
\hline 0.6 & $\begin{array}{l}1.091 \\
(5.99)\end{array}$ & $\begin{array}{l}1.164 \\
(2.32)\end{array}$ & $\begin{array}{l}0.434 \\
(3.69)\end{array}$ & 15.50 & 139.29 \\
\hline Control & $\begin{array}{l}0.937 \\
(5.55)\end{array}$ & $\begin{array}{l}0.249 \\
(2.85)\end{array}$ & $\begin{array}{l}0.497 \\
(4.19)\end{array}$ & 14.54 & 41.87 \\
\hline S.Em \pm & 0.088 & 0.446 & 1.12 & 0.47 & 3.32 \\
\hline C.D. at $5 \%$ & 0.27 & 0.135 & 0.36 & 2.34 & 10.06 \\
\hline
\end{tabular}

Figures in parenthesis indicate arcsine values 
These results are also confirmed by the findings of Awasthi et al., (1975) in litchi, Manusour and El-Slid, 1981 and Sharma et al., 1993 in guava and Forlov, 1967 in sweet orange.

\section{Effect of zinc sulphate on number of fruits per plant, fruit weight per tree and fruit yield per ha}

Foliar application of zinc sulphate significantly increased fruit weight and number. Trees treated with $0.6 \%$ zinc sulphate exhibited maximum fruit weight and numbers per tree than control (Table 2). It has been observed that double spray of $0.6 \%$ zinc sulphate produced significantly higher number of fruits per tree and yield per ha. Number of fruits per tree and yield per ha in general increased with increase in zinc sulphate concentrations and the maximum yield $(4.03 \mathrm{q} / \mathrm{ha})$ was recorded with foliar spray of 0.6 per cent zinc sulphate. The increase in number of fruits per tree and yield per ha were due to the more fruit set and less fruit drop. Similar findings were also reported by Hoda et al., (1978); Dixit et al., (1978), Sharma et al., (1998) and Rajkumar et al., 2014 in guava cv. Pant Prabhat. The increase in fruit yield with foliar application of zinc sulphate may be ascribed to increase in the fruit retention on the tree consequently reducing the pre-harvest fruit drop.

\section{Effect of zinc sulphate on leaf nutrient status}

Foliar application of zinc sulphate significantly improved the leaf $\mathrm{N}$ content of guava leaves (Table 3). All treated-trees showed higher level of leaf $\mathrm{N}$ contents than control. Trees sprayed with $0.6 \%$ zinc sulphate exhibited highest increase in the leaf $\mathrm{N}$ level than untreated trees. Similarly, all treated-trees showed significantly higher level of leaf $\mathrm{K}$ as compared to control. Application of $0.6 \%$ zinc sulphate resulted in maximum increase in $\mathrm{K}$ contents of guava leaves compared to control trees. However, the leaf concentration of $\mathrm{Zn}, \mathrm{P}$ content reduced with the increase in the concentration of zinc sulphate and minimum $(0.164 \%)$ was found with $0.6 \%$ zinc sulphate.

This increase in the level of macro-nutrients with foliar application of $\mathrm{Zn}$ may be due to some synergetic relationship between $\mathrm{N}, \mathrm{K}$ and $\mathrm{Ca}$ with $\mathrm{Zn}$. It is evident from the data in Table 3 that the leaf $\mathrm{N}_{2}, \mathrm{P}$ and $\mathrm{K}$ content were not affected by number of sprays. While $\mathrm{Ca}$, $\mathrm{Mg}$ and $\mathrm{Zn}$ content significantly affected by number of sprays. The maximum leaf nitrogen $(1.091 \%)$ and zinc (139.29 ppm) were recorded with $0.6 \%$, zinc sulphate while leaf $\mathrm{K}(0.434 \%)$ was found maximum with $0.4 \%$ zinc sulphate. This increase in the level of macro-nutrients with foliar application of $\mathrm{Zn}$ may be due to some synergetic relationship between $\mathrm{N}, \mathrm{K}$ and $\mathrm{Ca}$ with $\mathrm{Zn}$ (Samra, 1985; Sayed et al., 2004). While leaf $\mathrm{Ca}+\mathrm{Mg}$ remained unaffected. The above results are similar to the findings of Sharma and Bhattacharya (1989) in guava cv. Allahabad Safeda and Supriya et al., (1995) in guava cv. Allahabad Safeda and Supriya et al., (1995) in ber. Bhambata and Kanwar (1969) Hasani et al., (2012) in pomegranate also found decreased leaf $\mathrm{P}$ concentration with increased concentration of leaf zinc.

\section{References}

AOAC 1970. Official methods of analysis. Association of official agricultural chemists. $11^{\text {th }}$ Ed., Washington, D.C., USA.

Alloway, B. J. 2008. Zinc in Soils and Crop Nutrition. Brussels: The International Zinc Association.

Awasthi, R. P.; Tripathi, B. R. and Singh, A. 1975. Effect of foliar sprays of zinc on fruit drop and quality of litchi (Litchi 
chinensis Sonn.). The Punjab Horticultural Journal, 15 (1 \& 2) : 14 16.

Bahadur, Lal; Malhi, C. S. and Singh, Zora. 1998. Effect of foliar and soil applicaitonof zinc sulphate on zinc uptake, tree size, yield and fruit quality of mango. Journal of Plant Nutrition. 21 (3) : $589-600$.

Balakrishnan K.2001.Effect of foliar application of micronutrients on guava.Madras Agri.J.88(4-6):316-317.

Banik, B. C. and Sen, S. K. 1997. Effect of tree levels of zinc, iron, boron and their interactions on growth, flowering and yield of mango cv Fazli. Horticultural Journal. 10 (1) : 23 - 29.

Bardiya, M.C., Kundu, B.S. and Tauro, P. 1974. Studies on fruits wines: 1st Guava wines. Haryana. J. Hort. Sci., 3(3-4): 140-146.

Bhambata, J. R. and Kanwar, J. S. 1969. Paper presented at Hort. Seminar and P.A.U. Ludhiana. Quotid from Kanwar, J. S. and Randhawa, N. S. 1989 Micronutrient Research in New Delhi. pp 107 - 196.

Chang, K. L. and Bray, H. R. 1951. Determination of calcium and magnesium in soil and plant material. Soil Sci. 72 : 449 - 458.

Dixit, C. K.; Yamdagni, R. and Jindal, P. C. 1979. Effect of foliar applicationof zinv and iron on chkarasis and yield of kinnow. A Mandrin Hybrid. Prog. Hort. $10(1): 13-19$.

Frolov, A. I. 1967. The influence of micronutrients on flower and fruit drop vinodelic I Kingradarstvo. 27 (2) : 39 40.

Hasani M.,Zamani Z.,Savaghebi G., and Fatahi R.2012.Effects of zinc and manganese as foliar spray on pomegranate yield, fruit quality and leaf minerals. J.Soil Sci.Plant Nutr.12(3)471480.
Hoda, M. V.; Syamal, N. B. and Chhonkar, O. S. 1973. Growth substances and zinc on litchi fruit drop. The Indian Journal of Horticulture. 30 ( $1 \& 2): 456-460$.

Jackson, M. L. 1973. Soil chemical analysis. Asia Publishing House, New Delhi.

Jagtiani, J., Chan, H.T., Jr, Sakai, W.S. 1988. Tropical fruit processing. New York: Academic Press Inc.; pp. 9-43.

Jat, G. and Kacha, H. L. 2014. Response of guava to foliar application of urea and zinc on fruit set, yield and quality.Journal of AgriSearch.1(2):8991.

Jawanda, J. S. 1966. Zinc deficiency of citrus. A review. Punjab Hort. J. $6: 88-103$.

Manchanda, H. R. 1974. Chemical composition of sweet orange leaves (Citrus sinensis (L.) Osbeck) as affected by foliar application variety Pineapple. Indian Journal of Horticulture. 31 (1) : $34-37$.

Mansour, N. M.; El-Sud, Z. A. K. 1981. Effect of zinc sulphate on fruit set and yield of guava trees. Agricultural Research Review. 59 : 119 - 136.

Marschner, H. C. 1995. Mineral Nutrition of Higher Plants. London: Academic Press.

Rajkumar, Tiwari, J.P. and Shant, L. 2014. Effect of foliar application of zinc and boron on fruit yield and quality of winter season guava (Psidium guajava) cv. Pant Prabhat. Annals Agri. Bio Research 19(1): 105-108.

Rathore, D. S. 1976. Effect of season on the growth and chemical composition of guava (Psidium guajava L.) fruits. $J$. Hort. Sci. $51: 41-57$.

Razzaq K., Khan, A. S., Malik, A. U., Shahid M. and Ullah S. 2013. Foliar application of zinc influences the leaf mineral status, vegetative and reproductive growth, yield and fruit quality of 'kinnow' mandarin. Journal of Plant Nutrition. 36:10, 1479-1495.

Samra, N. R. 1985. Yield and fruit quality of 
Balady mandarin as affected by zinc and GA3 application. Journal of Agriculture Science Mansoura University 10: 14271432.

Sarolia, D. K., Rathore, N.S and Rathore, R. S. 2007. Response of zinc sulphate and iron sulphate sprays on growth and productivity of guava cv. Sardar. Curr. Agric. 31(1-2):73-77.

Sayed, R. A., Solaiman, B. M. and Abo-El Komsan, E. O. 2004. Effect of foliar sprays of some mineral nutrients, GA3 and or biostimulant on yield and fruit quality of Valencia orange trees grown in sandy soil. Egyptian Journal of Applied Sciences 19: 222-238.

Sharma, R. K., Thakur, S. and Kumar, R. 1993. A note on the effect of foliar feeding of zinc and GA on fruiting of guava trees (Psidium guajava L.). Haryana J. Hort. Sci. 22 (3) : 207 - 208.

Sharma, R. and Bhattacharya, R. K. 1989. Effect of foliar nutrition of zinc on the nutrient concentration of guava leaves. South Indian Hort. 37 (6) : 323 - 325.

Singh, Y. P. Tiwari, J. P. and Misra, K. K.
2003. Effect of micronutrients on fruit yield and physico-chemical composition of mango (Mangifera indica L.) fruit yield and physic0-chemical characters of mango cv.Dashehari. Prog.Hort. 35(1):34-37.

Supriya, L.; Bhattacharya, R. K. and Langthasa, S. 1996. Effect of foliar application of related and non-related zinc on growth and yield of Assam lemon (Citrus limon Burm F.). Horticultural Journal. 6 (1) : 35 - 38.

Swietlik, D. 1999. Zinc nutrition in horticultural crops. In: Horticultural Reviews, ed. J. Janick, pp. 109-118.New York: John Wiley \& Sons.

Swietlik, D. 2002. Zinc nutrition of fruit trees by foliar sprays. Acta Horticulturae 93: 123-129.

Yadav, R. K., Rana, G.S., Ahlavat, V.P. and Kumar, S. 2011. Effect of zinc application on growth and fruit drop of sweet orange (Citrus sinensis) CV.Jaffa. Haryana J.Horti.Sci. 36(3\&4):205-206.

\section{How to cite this article:}

Brijpal Bisen, J. P. Tiwari, K. K. Mishra and Shant Lal. 2020. Effect of Zinc Sulphate on Vegetative Growth, Yield and Leaf Nutrient Status of Guava (Psidium guajava L.). Int.J.Curr.Microbiol.App.Sci. 9(07): 1265-1273. doi: https://doi.org/10.20546/ijcmas.2020.907.145 